\title{
Refractive error changes in children with intermittent exotropia under overminus lens therapy
}

\author{
Alterações nos vícios refracionais em crianças com exotropia intermitente \\ submetidas ao tratamento por meio da hipercorreção com lentes negativas
}

\author{
Jayter Silva de Paula ${ }^{1}$ \\ Fuad Moraes Ibrahim² \\ Marcia Clivati Martins ${ }^{3}$ \\ Harley Edison Amaral Bicas ${ }^{4}$ \\ Antonio Augusto Velasco e Cruz ${ }^{5}$
}

\begin{tabular}{|l|}
\hline ABSTRACT \\
\hline Purpose: Intermittent exotropia may be decreased by stimulation of \\
accommodative convergence. Once excessive accommodation has been \\
related to myopia, our objective was to evaluate refractive errors changes \\
in children under overcorrecting minus lens therapy. Methods: A re- \\
trospective chart review of 21 children with intermittent exotropia was \\
performed. All patients were treated with occlusion, and a 13-patient \\
subset of them received overminus lens therapy (group A). Eight children \\
received spectacles as necessary (group B). Initial age, age interval, \\
initial spherical equivalent (SE), and magnitude of overcorrection were \\
considered as co-variables of the mean variation in refractive error (SE \\
of each eye) between groups, through a multivariate analysis. Results: \\
Overcorrection used in group A ranged from 0.5 D to 3.5 D (2.46 $0.87 \mathrm{D})$. \\
Although initial SE of each eye was significant different between group \\
A and B (OD - $p=0.02 ;$ OS - $p=0.01)$, initial age ( $p=0.69)$, age interval \\
( $p=0.90)$, and mean variation in refractive errors $(p=0.36)$ did not differ \\
between groups. Multivariate analysis with linear regression showed no \\
significantly difference regarding all co-variables enrolled. Conclusions: \\
Treatment of intermittent exotropia with overcorrecting minus lens did \\
not induce refractive errors changes, even considering age, treatment \\
period, initial spherical equivalent and overcorrection magnitude used. \\
\hline
\end{tabular}

Keywords: Exotropia; Eyeglasses; Myopia; Refractive error; Strabismus

\section{INTRODUCTION}

Intermitent exotropia has been treated with overminus lens in order to stimulate accomodative convergence ${ }^{(1-3)}$. This therapy may reduce an exotropic deviation in children under six years old, with minimal symptoms of asthenopia. We understand that accommodative convergence could be stimulated using undercorrected lens on hyperopic patients or overcorrected lens on myopic patients.

Several authors have shown no substantial relationship between exotropia or excessive accommodation and myopia progression ${ }^{(3-11)}$. Once myopic shift could be an undesired side effect in overminused patients, this present work was conducted in order to evaluate refractive errors changes in children with intermittent exotropia under overcorrecting minus lens therapy.

\section{METHODS}

A retrospective chart review of 21 charts of children under the age of 11 years, consecutively admitted to the Ophthalmologic Service of Ribeirão 
Preto Clinical Hospital between 1990 and 2000, was performed after approval of the local Ethics Committee. All patients presented intermittent exotropia and were treated according to best clinical judgment performed. In order to avoid methodological bias, all specific outcomes evaluated and statistical tests used were chosen according to a previous protocol written before the review.

Patients were excluded if they had any major ocular disease or other any ophthalmological problem related to specific ocular deviation. All patients were treated with occlusion, and a 13-patient subset of the total received overcorrecting minus lens therapy for at least 1 year (group A). Eight children received eyeglasses as necessary (group B).

All the refractions were performed by means of streak retinoscopy, and subjective refinement when possible, approximately 40 minutes after the instillation of $1 \% \mathrm{cy}$ clopentolate, administered twice. The use and the power of overcorrecting minus lens were decided by the first attending ophthalmologist, as well as other treatment modalities.

Refractive errors were recorded as the spherical equivalent of each eye during all individual treatment period or during the total follow-up period. The main outcome determination was a comparison of the change in refractive error in each of the study groups. Differences in the initial age, age interval, initial spherical equivalent of each eye (SE), and magnitude of overcorrection were considered as co-variables of the mean variation in refractive error (SE of each eye) between groups, through a multivariate analysis with linear regression (proc mixed-SAS 9.0).

\section{RESULTS}

During the course of this study, the period of treatment and follow-up did not differ between groups. Patients of group A received overminus lens therapy for $4.61 \pm 2.36$ years (ranged from 1 to 9 years), and patients of group B were treated for $4.75 \pm 2.6$ years (ranged from 1 to 8 years). Male:female proportion was 2.25:1 in the group A and 1:1 in the group B.

At the time of initial examination, initial age was not significantly different $(p=0.69)$ between group A and group B (Table 1). Although initial SE of each eye was significant different (group A x group B: OD - $p=0.02$; OS - $p=0.01$ ), age interval, magnitude of overcorrection and mean variation of refractive errors (considering each eye) did not differ between groups (Table 1). Mean change in refractive error (without specification of which eye) also did not differ between groups ( $p=0.36$ ) (Figure 1). Multivariate analysis with linear regression showed no significantly difference between groups regarding all co-variables enrolled: initial age $(p=0.40)$, age interval $(p=0.43)$, initial SE of each eye $(p=0.27)$, and magnitude of overcorrection $(p=0.24)$.

\section{DISCUSSION}

Excessive accommodation stimulus has questionable relation with the shift toward myopia. Some authors ${ }^{(3)}$ have suggested that myopic patients overminused for exotropia became more myopic; however they considered the amount of myopia progression normal for myopic children of that age. Other studies ${ }^{(5,12)}$ have also shown lack of association of overcorrection in exotropia and refractive changes. Despite Kushner ${ }^{(12)}$ had carefully differentiated groups based on initial SE error (myopic/ hyperopic), he did not use a multivariate analysis.

On the other hand, Repka et al. ${ }^{(13)}$ found that patients with hyperopia and accommodative esotropia who were treated with spectacles incorporating their full cycloplegic correction tended to lose hyperopia at a slower rate than children described in normative data. This finding could suggest that the wearing of hyperopic spectacles might retard emmetropization because they decrease the demand for accommodation.

Interestingly, other authors have observed that hyperopic children showed a small myopic shift per year while they had hyperopia but have a more rapid myopic shift once they became myopic ${ }^{(14)}$. This has given rise to another hypothesis, previously speculated ${ }^{(15)}$, that accommodation possibly prevents myopia because more accommodation would be occurring in hyperopic than myopic children.

Several explanations for the observation of some studies ${ }^{(6,14,16-17)}$, which have demonstrated that the shift toward myopia is greater in initially myopic than initially hyperopic children, can be elaborated. Some authors believe that overcorrecting minus lens may be more accidentally prescribed in patients who were already myopic than in patients who were hyperopic, because myopic patients were already wearing spectacles ${ }^{(3,12)}$. This explanation has not been proven, especially if considering less myopization in older children who have used negative lenses.

Although we did not perform a prospective randomized study, our comparison of two groups of intermittent exotropic children treated (group A) or not (group B) with overminus lens fail to prove a relation between treatment and myopic shift. As described, less than $-1.0 \mathrm{D}$ (mean) variation occur in the group A. Although a little bit greater variation was observed in group $\mathrm{B}$, there was no significant difference regarding changes in refractive errors between both groups $(\mathrm{P}=0.36)$. Group B had significantly more myopic patients and this fact could influence that little difference observed in the comparison of SE variation.

Because initial SE and other parameters could interfere in the final analysis, we carefully considered probable confusion co-variables (initial age, age interval, initial SE of each or any eye, and magnitude of overcorrection). In order to analyze all parameters, a model of multivariate analysis with mixed procedures of regression was made and showed no significant differences, considering all co-variables. 


Table 1. Distribution of co-variables studied and the mean variation in refractive error in group A (overcorrection minus lens therapy) and B
(no overcorrection)

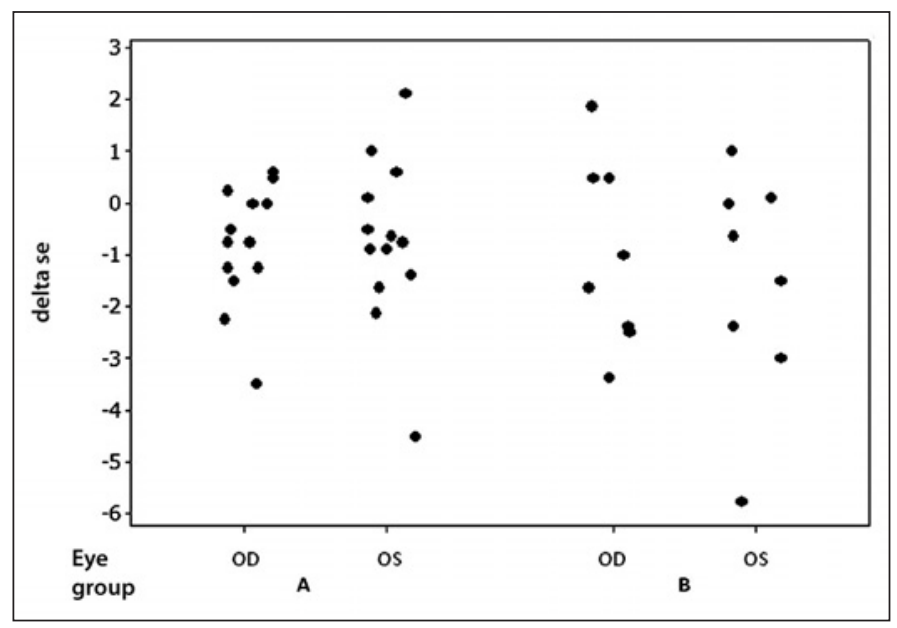

Figure 1 - Distribution of individual values of the variable mean SE variation (delta se) of all subjects

Our data are an interesting addition to the previous discussion, suggesting that increasing accommodative lag is not relevant to myopia progression, at least for exotropic patients.

Based on our results, treatment of intermittent exotropia with overcorrecting minus lens may be a safe procedure and did not induce refractive errors changes, even considering initial age, treatment period, initial spherical equivalent and overcorrection magnitude used.

\section{ACKNOWLEDGEMENT}

This work was supported by FAEPA. There is no proprietary interest in this study. The authors gratefully acknowledge the theoretical discussion and assistance of Frank Thorn, OD, and the source of the first list of medical records provided by Christine Mae Morello Abbud, MD.

\section{RESUMO}

Objetivo: A exotropia intermitente pode ser diminuída pela estimulação da convergência acomodativa. Uma vez que uma acomodação excessiva tem sido relacionada à miopização, o objetivo deste trabalho foi o de avaliar alterações nos vícios de refração de crianças submetidas à hipercorreção com lentes negativas. Métodos: Foi realizada revisão dos prontuários de 21 crianças com exotropia intermitente. Todos os pacientes foram tratados com oclusão, sendo que 13 deles foram submetidos à hipercorreção com lentes negativas (grupo A). As 8 crianças restantes receberam prescrições ópticas conforme necessário pelas suas ametropias (grupo B). A idade inicial, tempo de tratamento, equivalente esférico (EE) inicial e magnitude da hipercorreção foram considerados como covariáveis na análise das diferenças das médias de erro refrativo (EE de cada olho) entre os grupos, pela análise multivariada. Resultados: A hipercorreção utilizada no grupo A variou entre $0,5 \mathrm{D}$ e 3,5 D (2,46 $\pm 0,87 \mathrm{D})$. Embora o EE inicial de cada olho ter sido significativamente diferente entre os grupo A e B (olho direito - $p=0,02$; olho esquerdo $-p=0,01)$, a idade inicial $(p=0,69), \mathrm{o}$ tempo de tratamento $(p=0,90)$ e a variação média nos erros refrativos $(p=0,36)$ não diferiram entre os grupos. A análise multivariada com regressão linear não mostrou diferença significativa, considerando as covariáveis em questão. Conclusões: O tratamento de crianças com exotropia intermitente por meio de hipercorreção óptica com lentes negativas não induziu alterações nos vícios de refração, mesmo considerando fatores como idade inicial, o tempo de tratamento, equivalente esférico inicial e a magnitude da hipercorreção utilizada.

Descritores: Exotropia; Óculos; Miopia; Erros de refração; Estrabismo

\section{REFERENCES}

1. Kennedy J. The correction of divergent strabismus with concave lenses. Am J Optom Arch Am Acad Optom. 1954;31:605-14.

2. Iacobucci S, Mertanyi E, Giles C. Results of overminus lens therapy on postoperative exodeviations. J Pediatr Ophthalmol Strabismus. 1986;23:287-91.

3. Caltreider N, Jampolsky A. Overcorrecting minus lens therapy for treatment of intermittent exotropia. Ophthalmology. 1983;90(10):1160-5.

4. Fulton A, Dobson V, Salem D, Mar C, Peterson R, Hansen R. Cycloplegic refractions in infants and young children. Am J Ophthalmol. 1980;90(2):239-47.

5. Rutstein RP, Marsh-Tootle W, London R. Changes in refractive error for exotropes treated with overminus lenses. Optom Vis Sci. 1989;66(8):487-91.

6. Slataper FJ. Age norms of refraction and vision. Arch Ophthalmol. 1950; 43(3):466-81.

7. Dyer JA. Role of cycloplegics in progressive myopia. Ophthalmology. 1979; 86(5):692-4. 
8. Brodstein RS, Brodstein DS, Olson RJ, Hunt SC, William RR. The treatment of myopia with atropine and bifocals: a longterm prospective study. Ophthalmology. 1984;91(11):1373-9.

9. Brenner R. Further observations on the use of atropine in the treatment of myopia. Ann Ophthalmol. 1985;17(2):137-40.

10. Bedrossian R. The effect of atropine on myopia. Ophthalmology. 1979;86(5): 713-7.

11. Zylbermann R, Landau D, Berson D. The influence of study habits on myopia in Jewish teenagers. J Pediatr Ophthalmol Strabismus. 1993;30(5):319-22.

12. Kushner BJ. Does overcorrecting minus lens therapy for intermittent exotropia cause myopia? Arch Ophthalmol. 1999;117(5):638-42.
13. Repka M, Wellish K, Wisnicki H, Guyton D. Changes in the refractive error of 94 spectacle-treated patients with acquired accommodative esotropia. Binoc Vision. 1988;4(1):15-21.

14. Goss D. Linearity of refractive change with age in childhood myopia progression. Am J Optom Physiol Opt. 1987;64(10):775-80.

15. Goss D. Overcorrection as a means of slowing myopic progression. Am J Optom Physiol Opt. 1984;61(1):85-93.

16. Goss D, Winkler R. Progression of myopia in youth: age of cessation. Am J Optom Physiol Opt. 1983;60(8):651-8.

17. Mantyjarvi MI. Changes of refraction in schoolchildren. Arch Ophthalmol. 1985;103(6):790-2. 